\title{
EFFECTS OF A BIOLOGICAL ADDITIVE AND SEALING TECHNIQUE ON THE AEROBIC STAB ILITY OF WHOLE-PLANT CORN SILAGE
}

\author{
M. E. Uriarte, K. K. Bolsen, and R. V. Pope
}

\section{Summary}

The objectives of this whole-plant corn study were to determine the effects of a biological additive and sealing technique on yeast and mold populations; and to examine the relationship between the microbial and chemic al changes in the silages during exposure to air. Whole-plant corn was harvested at $80 \%$ milkline $(36 \% \mathrm{DM})$, and ensiled at a density of $43 \mathrm{lb}$ of fresh matter $/ \mathrm{ft}^{3}$. One-half of the pre-ensiled forage was treated with a biological additive (A), which contained a mixture of bacteria and enzymes (supplied by Alltech, Inc., Nicholasville, KY); the other one-half of the pre-ensiled forage was the untreated control (C). One-half of the silos in the $\mathrm{A}$ and $\mathrm{C}$ groups were sealed immediately after filling $(\mathrm{S}=$ sealed $)$ and the remaining silos were sealed $48 \mathrm{hr}$ after filling $(\mathrm{DS}=$ delayed seal). Treatments consisted of combinations of the two main effects: additive ( $\mathrm{A}$ and $\mathrm{C}$ ) and sealing technique $(\mathrm{S}$ and DS). There were three, 5-gallon capacity, laboratory silos per treatment. Silos were opened after 150 days, and the chemical and microbial compositions and aerobic stability of the silages determined. All four silages were moderately stable during the period of exposure to air. The C, DS silage was the first to show a rise in temperature, occurring after $65 \mathrm{hr}$ of exposure to air. The two DS silages were $48 \mathrm{hr}$ less stable than their $\mathrm{S}$ counterparts, and the two A silages were $24 \mathrm{hr}$ more stable than their $\mathrm{C}$ counterparts. Deterioration of the silages during exposure to air was accompanied by an increase in temperature and $\mathrm{pH}$, a decrease in lactic acid content, and a rapid increase in the lactate-assimilating yeast population. Treatment with a biological additive significantly improved aerobic stability, but the mechanism of action was not evident. Delayed sealing after the silos were filled reduced the aerobic stability of the silages.

(Key Words: Corn Silage, Aerobic Deterioration, Silage Additives.)

\section{Introduction}

Efficient forage preservation as silage requires minimizing losses during the aerobic, fermentation, storage, and feedout phases. Although the efficiency of the fermentation phase has improved during recent years, the same cannot be said about aerobic stability during the feedout phase. Wellpreserved silages are often more prone to aerobic deterioration than their poorly preserved counterparts.

The addition of homo fermentative lactic acid bacteria (LAB) has improved silage quality by promoting a fast and efficient production of lactic acid that results in a rapid decrease in $\mathrm{pH}$. This has not necessarily improved aerobic stability at feedout because aerobic stability has often been less for homolactic compared to heterolactic silages.

Enzymes have been used for years as silage additives; and the most common enzymes are cellulases, hemicellulases, xylanases, pectinases, and amylases. Enzymes breakdown complex polysaccharides (fiber and starch) to simple sugars, which provide LAB with more substrate for the production of lactic acid, but enzymes have had variable and inconsistent effects on aerobic stability. 
The objectives of this study with wholeplant corn were to determine the effects of a biological additive and sealing technique on yeast and mold populations; and to examine the relationship between the microbial and chemical changes in the silages during exposure to air.

\section{Materials and Methods}

Silage Preparation. Whole-plant corn was harvested at $80 \%$ milkline $(36 \% \mathrm{DM})$ on September 21, 1999. It was precision chopped to a 0.5 -inch theoretical particle size, ensiled in laboratory silos, and packed at a density of $43 \mathrm{lb}$ of fresh forage per cubic foot. One half of the pre-ensiled forage was treated with a biological additive (A) that contained a mixture of bacteria (e.g., Streptococcus faecium, Pediococcus acidilactici, Lactobacillus plantarum, Bacillus pumulis) and enzymes (e.g., cellulase, hemicellulase, amylase, and pentosanase) (provided by Alltech, Inc., Nicholasville, KY). The other half of the pre-ensiled forage was the untreated control (C). One-half of the silos in the $\mathrm{A}$ and $\mathrm{C}$ groups were sealed immediately after filling $(\mathrm{S}=$ sealed $)$, and the other half sealed $48 \mathrm{hr}$ after filling (DS = delayed sealed).

The laboratory silos were 5-gal capacity plastic pails. Silos were filled using a hydraulic press and fitted with a Bunsen valve to allow gases to escape. Treatments consisted of combinations of the two main effects: additive ( $\mathrm{A}$ and $\mathrm{C}$ ) and sealing technique (S and DS).

Aerobic Stability Measurements and Silage Composition. The silos were opened after 150 days. All three replicates from each treatment were mixed and sampled. The composited and mixed, and pooled samples for each treatment were placed in 1.7-gal capacity polystyrene foam containers. There were 10 containers per treatment, and the silages were exposed to air for 6 days. Thermocouples were placed in the center of the silage in each container, and temperature of silages was recorded daily at 06, 12, 18 and $24 \mathrm{hr}$. Ambient room temperature was kept constant at $24^{\circ} \mathrm{C} \pm 0.5$. A silage was considered aerobically unstable when the temperature raised $1.5^{\circ} \mathrm{C}$ above room temperature. Two containers of each treatment were removed on days 1 through 4 , and two samples were taken: one was frozen for further chemical analysis (e.g., pH, DM, lactic acid, and volatile fatty acids) and the other analyzed immediately for microbial counts (e.g., lactic acid bacteria, yeast and mold, and lactate assimilating yeast).

Statistical Analysis. The treatment structure was a two-way with no independent replications of the two-way treatment combinations. Data on chemical composition and microbial counts were analyzed by the GLM and Mixed procedures of SAS using techniques for non-replicated experiments. Results are reported as least-square means. Observed differences were considered to be significant at $P \leq 0.05$.

\section{Results}

The chemical composition of the corn silages after 150 days of storage and a 6-day exposure to air is shown in Table 1. Silage $\mathrm{pH}$ and lactic and acet ic acid concentrations indicated efficient preservation. Exposure of the silages to air led to an increase in $\mathrm{pH}$ and a decrease in lactic and acetic acid contents in the delayed seal silages.

All four corn silages were moderately stable during the exposure to air (Figure 1). The first increase in temperature occurred after $65 \mathrm{hr}$ in the cont rol silage where sealing was delayed (C, DS), and the additivetreated, delayed seal silage (A, DS ) was the next to heat (after $89 \mathrm{hr}$ ). Extremely good aerobic stability was observed in the two sealed silages. The $\mathrm{C}, \mathrm{S}$ silage was aerobically stable for $113 \mathrm{hr}$; the A, S silage was stable for $137 \mathrm{hr}$. The two DS silages were $48 \mathrm{hr}$ less stable than their S counterparts, and the two A silages were $24 \mathrm{hr}$ more stable than their $\mathrm{C}$ counterparts.

The effect of sealing technique on $\mathrm{pH}$ changes in the corn silages during exposure to air is shown in Figure 2. The $\mathrm{pH}$ of the $\mathrm{C}$, DS silage increased dramatically from day 2 to 3 , whereas $\mathrm{pH}$ of the $\mathrm{A}$, DS silage increased from day 3 to 4 (data not shown). Both sealed silages remained aerobically 
stable throughout the first 4 days of exposure to air, with $\mathrm{pH}$ values of 3.5 for the control silage and 3.7 for the additive-treated silage.

Lactic acid content of silages was affected by interactions $(P<0.05)$ between sealing technique and time of exposure to air $(P<0.05)$ (Figure 3$)$ and between sealing technique and additive (Figure 4). Lactic acid content in the delayed sealed silages decreased dramatically from day 2 to 3 of exposure to air. The lactic acid content in the sealed silages did not change throughout the 4-day exposure to air. The $\mathrm{C}, \mathrm{S}$ silage had a much higher acetic acid content than it's a, S silage counterpart (Table 1). Sealed and delay sealed additive-treated silages had numerically similar lactic and acetic acid values.

The microbial composition of the corn silages after 150 days of storage and a 4-day exposure to air is presented in Table 2 . Additive and sealing technique had no significant effects on yeast and mold populations. Most of the yeast were lactic acidassimilating yeasts (LAY) and counts at day 0 ranged $10^{2}$ to $10^{5} \mathrm{cfu}$ per $\mathrm{g}$ of silage (fresh basis). Aerobic deterioration of the two delayed seal silages was accompanied by an increase $(P=0.06)$ in the LAY population
(Figure 4). The increase in LAY during exposure to air also was accompanied by increases in temperature and $\mathrm{pH}$ and a decrease in the lactic acid content of the silages.

\section{Conclusions}

The biological additive and delayed sealing had clear effects on the aerobic stability of the corn silages. Treatment with a biological additive significantly improved aerobic stability, but the mechanism of action was not evident. Delayed sealing after the silos were filled reduc ed the aerobic stability of the silages. The $\mathrm{S}$ silages were $48 \mathrm{hr}$ more aerobically stable than their DS counterparts, and the two A silages were 24 hr more stable than their $\mathrm{C}$ counterparts.

Silage management practices that eliminate the presence of air should minimize the active role played by aerobic microorganisms in the deterioration process. More care should be taken to reduce air infiltration by timely and proper sealing, and maintenance of the quality of the seal. The effects of homolactic bacterial inoculants and enzymes on the aerobic deterioration process is not clear or consistent, and fact ors other than air per se need to be studied.

Table 1. pH and Chemical Composition of the Four Corn Silages Before (Day 0) and After Exposure to Air (Day 4)

\begin{tabular}{|c|c|c|c|c|c|c|}
\hline \multirow[b]{3}{*}{ Treatment } & \multicolumn{2}{|c|}{$\mathrm{pH}$} & \multicolumn{2}{|c|}{ Lactic acid $^{1}$} & \multicolumn{2}{|c|}{ Acetic acid ${ }^{1}$} \\
\hline & \multicolumn{2}{|c|}{ Day } & \multicolumn{2}{|c|}{ Day } & \multicolumn{2}{|c|}{ Day } \\
\hline & 0 & 4 & 0 & 4 & 0 & 4 \\
\hline \multicolumn{7}{|l|}{ Control } \\
\hline $\mathrm{S}(35.1)$ & 3.7 & 3.6 & 4.5 & 4.4 & 2.4 & 0.2 \\
\hline DS (33.8) & 3.7 & 8.0 & 4.9 & 0.3 & 1.4 & ND \\
\hline \multicolumn{7}{|l|}{ Additive $^{2}$} \\
\hline $\mathrm{S}(33.0)$ & 3.5 & 3.7 & 4.1 & 3.9 & 1.4 & 0.2 \\
\hline DS (32.5) & 3.6 & 8.2 & 4.5 & 1.5 & 1.5 & ND \\
\hline
\end{tabular}

${ }^{1}$ Percent of the silage DM.

${ }^{2}$ Percent of the DM of the corn silages is shown in parenthesis.

$\mathrm{ND}=$ not detected. 
Table 2. Microbial Composition (Log CFU per $g$ of Fresh Material) of the Corn Silages Before (Day 0) and After Exposure to Air (Day 4)

\begin{tabular}{|c|c|c|c|c|}
\hline \multirow[b]{3}{*}{ Treatment } & \multicolumn{2}{|c|}{ Yeast and Mold } & \multicolumn{2}{|c|}{ Lactate Acid-Assimilating Yeast } \\
\hline & \multicolumn{2}{|c|}{ Day } & \multicolumn{2}{|c|}{ Day } \\
\hline & 0 & 4 & 0 & 4 \\
\hline \multicolumn{5}{|l|}{ Control } \\
\hline S & NA & 9.2 & 4.9 & 8.2 \\
\hline DS & 2.9 & 9.7 & 5.7 & 9.4 \\
\hline \multicolumn{5}{|l|}{ Additive } \\
\hline S & NA & 9.1 & 5.0 & 9.0 \\
\hline DS & 5.1 & 8.6 & 5.5 & 8.7 \\
\hline
\end{tabular}

$\mathrm{NA}=$ sample not analyzed.

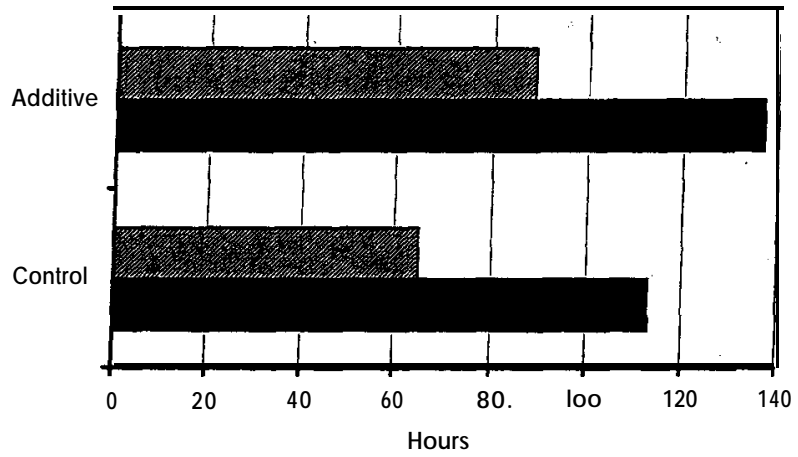

Fig. 1. Hours to the Initial Rise in Temperature for the Four Corn Silages during Exposure to Air. $\square$ Sealed, $\square$ Delayed seal

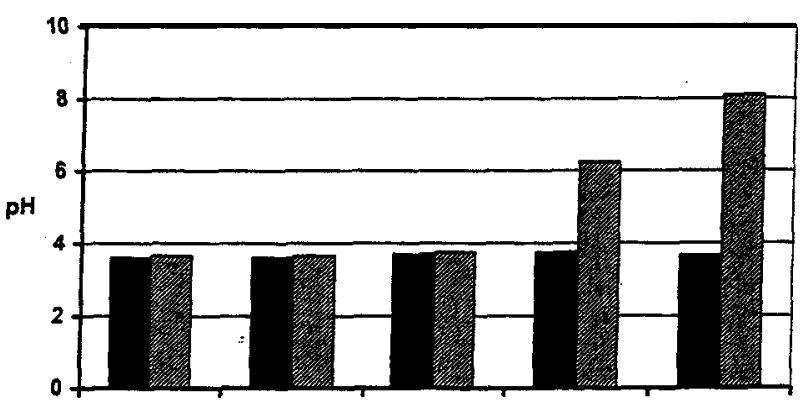

Days

Fig. 2. pH Changes in the Corn Silages during Exposure to Air: Effect of Sealing Technique. $\square$ Sealed, $\square$ Delayed seal

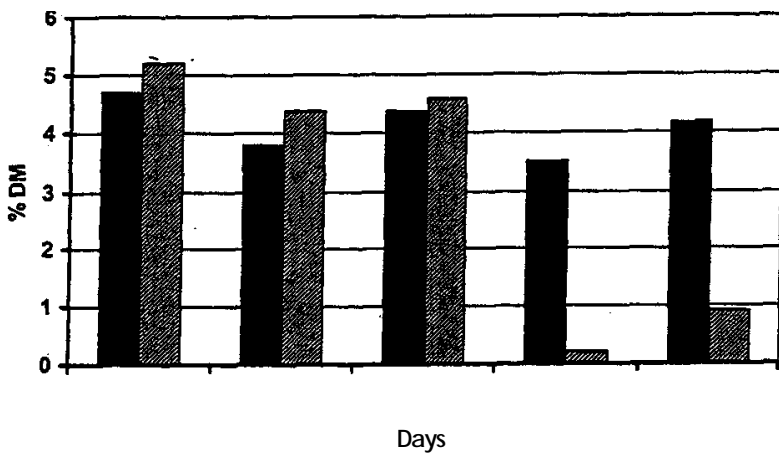

Fig. 3. Lactic Acid Changes (\% of the silage DM) in the Corn Silages during Exposure to Air: Effect of Sealing Technique. $\square$ Sealed, $\square$ Delayed seal

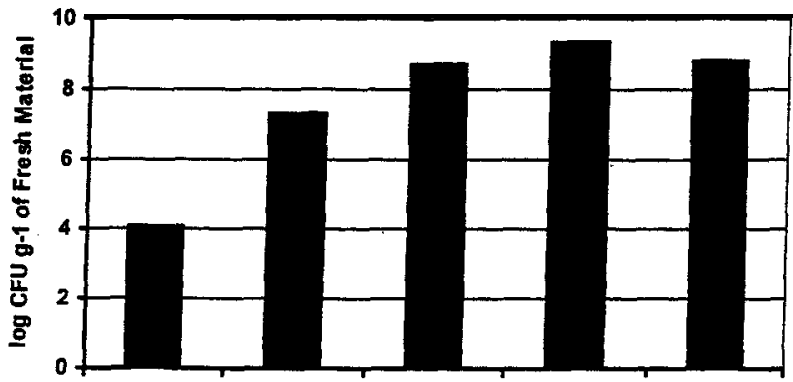

Days

Fig. 4. Lactic acid-assimilating yeast populations in the corn silages during exposure to air. 